\title{
Decolonising Labour, Reclaiming Subaltern Epistemologies: Brazilian Domestic Workers and the International Struggle for Labour Rights
}

\section{Louisa Acciari*}

\begin{abstract}
This study explores the labour rights discourse produced by Brazilian domestic workers. It shows that the 2015 Brazilian legislation which extended labour rights to domestic workers was not simply a 'boomerang effect' of ILO Convention 189 on decent work for domestic workers, or a case of the 'vernacularisation' of global rights. Indeed, domestic workers have agitated for equal labour rights since 1936, and articulated the specific rights contained in the new legislation decades before their institutional recognition. Therefore, rather than being an instance of the translation of pre-existing global frameworks at the local level, the case of domestic workers demonstrates the ability of subaltern groups to transnationalise their demands, suggesting that the global South should not be conceived only as a place of rights reception, but also as a place of rights production. In this context, I trace the genealogy of the labour rights discourse as imagined and mobilised by domestic workers in Brazil, and examine the ways in which they have travelled between their subaltern location, the Brazilian state and the international agenda about 'decent work'.
\end{abstract}

Key words: domestic work; labour rights; subaltern knowledge; Brazil; transnational movements.

\section{Introduction}

Domestic workers, the vast majority of whom are racialised and precarious women, are often presented as one of the most vulnerable groups of workers (Fish 2017). There are some 60 million domestic workers worldwide, of whom $83 \%$ are women and $17 \%$ are migrants (ILO 2013; ILO 2016). In Brazil, where domestic workers are mostly internal migrants, there were 6.4 million such workers in 2013, of whom $93 \%$ were women and $60 \%$ were black women. On average, they earn $60 \%$ less than other workers, and only $30 \%$ of them

* London School of Economics and Political Science (LSE), London, United Kingdom of Great Britain and Northern Ireland; 1.acciari@lse.ac.uk. ORCID iD 0000-0002-2335-7948. 
are formal workers (DIEESE 2013). ${ }^{1}$ The lack of proper labour regulation in this sector has led Brazilian scholars to characterise domestic work as a legacy of slavery (BernardinoCosta 2007; Pinho and Silva 2010). In fact, the high proportion of black women performing domestic work is intrinsically linked to Brazil's colonial history and its gendered and racial division of labour.

In 2011, the International Labour Organisation (ILO) adopted Convention 189, which requires member states to ensure that domestic workers enjoy 'fair terms of emloyment as well as decent working conditions.'2 This international norm had a positive impact on Latin American countries (Poblete 2018), including Brazil, where similar legislation was adopted in 2015, following on a 2013 Constitutional amendment that prohibited discrimination against domestic workers. Convention 189 has worked to encourage accelerated legislative reform, and to suggest its substance. However, in Brazil, the struggle for equal rights has a longer history. Indeed, it can be traced back to 1936 when the domestic worker and activist Laudelina de Campos Mello created the first association of domestic workers, claiming the right to form labour unions and to receive social security (Pinto 2015). For decades, domestic workers have been contesting the notion that their work is not proper work, and demanding their inclusion in the Labour Code.

This study examines the discourse of Brazilian domestic workers about labour rights, and argues that it constitutes a subaltern epistemology of rights. Indeed, in Brazil, their demands for equal rights are embedded in the colonial legacy and the national welfare state model in which citizenship is linked to the status of workers. Since 1936, organised domestic workers have been reclaiming the value of their labour, and pressing for their full recognition as workers. In the process, they have challenged the gendered and racial division of labour inherited from colonialism, and consequently the entire Brazilian social order.

Given this, I argue that the Brazilian legislation should not be seen only as a 'boomerang effect' (Keck and Sikkink 1998) or a case of the 'vernacularisation' of global rights frameworks (Levitt and Merry 2009). Indeed, domestic workers began to articulate their discourse on labour rights decades before the 2015 law and ILO Convention 189, which suggests an ability to transnationalise their demands that goes beyond an adaptation of international rights frameworks at the local level. While rights discourses do not have a fixed origin or unique directionality, the case of domestic workers shows that subaltern groups in the global South can be producers of rights discourses and not just translators of pre-existing 'global' frameworks. I describe this phenomenon as 'transnationalisation from below' to insist on the capacity of subaltern movements to transnationalise their knowledge and epistemologies, and influence international standards. These transnational travels can coexist, and ILO Convention 189 certainly provides local movements with new organisational instruments. Nonetheless, it is important to consider the bottom-up movement through which subaltern groups succeed in getting heard at the international level, and to pay attention to their agency in the process of rights-making.

Brazilian domestic workers' unions are one actor among a diversity of domestic workers' organisations worldwide, and this case study alone cannot explain the reasons for 
the adoption of ILO Convention 189. Rather, I seek to demonstrate that the particular language of labour rights produced by domestic workers has a longer history, and that domestic workers played an active role in the formation of this international norm. In addition, I argue that the 2015 Brazilian legislation has not just resulted from the ILO Convention, but also reflects decades of struggles by domestic workers. Furthermore, by tracking the epistemology of the rights of domestic workers, I will show that the global South should not be conceived only as a place of rights reception, but also as a place of rights and knowledge production (Barreto 2012; Mignolo 2011; Sikkink 2014). Thus, I propose to trace the genealogy of the labour rights discourse as imagined and mobilised by domestic workers in Brazil, and to examine the ways in which this discourse has travelled between domestic workers' subaltern location, the Brazilian state and the international agenda on 'decent work.'

This study draws on two years of field work conducted between 2015 and 2017 among members of domestic workers' unions affiliated to the National Federation of Domestic Workers (Federação Nacional das Trabalhadoras Domésticas, or FENATRAD) in Brazil. I interviewed FENATRAD leaders as well as the leaders of local unions in the states of São Paulo and Rio de Janeiro. Taken together, these states account for $40 \%$ of the domestic workforce (CUT-RJ and Sintell-Rio 2013; DIEESE and FES 2015). I also collected internal documents such as pamphlets and minutes of meetings, which enabled me to trace their history. Labour unions for domestic workers are typically under-resourced, have no paid staff, have very low memberships (see Costa Furno 2016), and rely on the goodwill of their allies for office space. The leaders are volunteers, and are usually either retired domestic workers, or still active in this capacity.

In the next section I review the feminist literature on human rights and propose a framework for conceiving of the global South, and subaltern groups in particular, as producers of rights discourses. Next, I map the history of the Brazilian domestic workers' movement and their struggle for labour rights. Following this, I discuss the ways in which the demands of Brazilian domestic workers have travelled transnationally, and how they have resonated with the ILO's agenda on 'decent work.' Then, I reflect on the significance of these processes, and argue that the Brazilian legislation challenges the colonial social order by recognising domestic work as work. The last section concludes.

\section{Rethinking the global South as a place of rights production}

Human rights have been widely debated within feminist and development studies. While they are recognised as necessary (MacKinnon 1994; Molyneux and Razavi 2002; Spivak 2003), the conditions of production of human rights, the power relations they entail and reproduce and their effects on the ground remain the object of critical inquiries (Collins et al 2010). Rights on their own cannot change the context that has produced social inequalities, which sometimes makes rights hard to enforce, or even disconnects them from local realities (Bradshaw 2006; Gideon 2006; Kabeer 2004; Kabeer 2015). Furthermore, social groups often rely on the state to implement and guarantee their rights, which raises the 
question of the actual capacity and willingness of the state to enforce those rights, as well as the type of relationship social movements can have with the state without excessively compromising their objectives (Cornwall and Molyneux 2006; Couso 2007).

Some authors have argued that for rights to be effective, they presuppose certain sorts of liberal subjects, responding to an abstract universal and Eurocentric conception of the human (Golder 2014; Spivak 2003). In this perspective, human rights become a form of regulation of bodies and subjectivities. Feminist scholars contend that they lock women into a position of victims, mothers or heterosexual feminine subjects, thereby reproducing the very power imbalances that maintain the oppression of women (Brown 2000; Cornwall et al 2008; Corrêa 2016). Moreover, post-colonial feminists have affirmed that human rights discourses are embedded in, and sustained by, unequal global power relations. Indeed, human rights create agents who can save, as opposed to populations in need of saving (Mohanty 1988; Spivak 2003), and have occasionally been mobilised by the West to justify imperialist interventions (Abu-Lughod 2002; Mahmood 2011).

Yet, rights are wanted, claimed and used by social movements in the global South. In fact, rights are being increasingly mobilised to the point that some talk about a judicialisation of politics (Couso et al 2013; Sieder et al 2005). At the national level, the law can open up opportunities for social movements to structure themselves in order to claim a right, or to influence policy-making. Rights then act as a source of identity and legitimacy, and can open up possibilities for collective action (Bo Nielsen 2015; Jacquot and Vitale 2014; Kay 2011). At the international level, the existence of conventions and norms can be an efficient way for social movements to become more visible, capture resources or force non-responsive states to adapt national laws (Keck and Sikkink 1998; Sikkink 2005).

Thus, social actors in the global South are not passive receptors of rights imposed on them; they actively claim and negotiate rights, and transform human rights discourses into concrete local demands (Brinks et al 2015; Della Porta and Tarrow 2005; Dufour and Giraud 2007; Kay 2011). Discussions about the vernacularisation of rights have precisely focused on the ways in which the local and the global are interconnected (Levitt and Merry 2009; Reilly 2011). The term 'vernacularisation' refers to a process in which local movements adapt 'globally generated ideas' (Levitt and Merry 2009) to their particular context. This process involves the 'translation' of pre-existing international frameworks by local experts in order to make rights intelligible to women at the grass roots, thereby enabling them to use those frameworks for their mobilisation (see for instance Chua 2015; Rajaram and Zararia 2009).

According to García-Del Moral (2016), the assumption that these 'translators' are a distinct group of actors conveys an idea of women at the grassroots as being unable to be active agents of human rights promotion, which reproduces a binary distinction between 'targets' and 'translators' of rights. She argues that women at the grass roots should also be regarded as actors in the process of rights translation and adaptation. In a slightly different perspective, Sousa-Santos and Rodríguez-Garavito (2005) argue that subaltern movements not only adapt rights frameworks, but also challenge and transform 
Western-centred rights frameworks into counter-hegemonic discourses. This creates what they call a 'subaltern cosmopolitan legality'

While insisting on the active role of subaltern movements and women at the grassroots in transforming rights, these perspectives, like that of vernacularisation, nonetheless risk reproducing a dichotomy between the North as a place of rights production and the South as a place of rights reception. In order to move beyond this dichotomy, Sumi Madhok (2017: 485) suggests that a 'vernacular rights culture' approach be adopted to capture the instances where movements have developed 'their own languages of rights and entitlements grounded in specific political imaginaries, justificatory premises, and subjectivities.' Thus, rather than assuming a unique North-South directionality, we should examine how 'rights languages are constituted and articulated by marginal subjects' (Madhok 2017: 485). Furthermore, in some cases, the very act of claiming a right goes beyond demanding inclusion in an existing framework; it can also transform the rights framework itself (Dunford and Madhok 2015; Madhok 2017).

In Brazil, the category of 'work' has to be expanded in order to include domestic workers' demands. Indeed, domestic workers are the only professional category to be excluded from the Labour Code, which is justified on the grounds that their labour is 'non-lucrative' (Law 150/2015, Article 1). To understand this historical exclusion, I use the framework of the coloniality of power as developed by Quijano $(2000,2007)$, which refers to 'the systematic classification of the world's populations around the idea of race' (Quijano 2000: 535). In Latin America, this creates a racial division of labour within which white colonisers possess the means of production while black and indigenous people, descendants of slaves, must sell their labour power. Lugones (2010) and Gutiérrez-Rodriguez (2013) have integrated gender with the concept of the coloniality of power to provide a more accurate account of the oppression experienced by women in post-colonial contexts, which Lugones (2010) calls the 'coloniality of gender'.

Thus, the particular intersection of gender, race and class oppression in the Brazilian post-colonial context has meant that the work of social reproduction, performed mostly by poor black women descended from slaves, remains invisible and unrecognised. The subalternisation of domestic work can be conceived as being part of the coloniality of labour in Brazil. Consequently, domestic workers' struggle to be recognised as workers represents a profound challenge to the colonial order and the rights framework. By tracking domestic workers' discourses of and mobilisation for equal labour rights, I aim to show that this subaltern group has produced a particular epistemology of rights that has the potential to decolonise labour in Brazil. In doing so, I inscribe myself within existing endeavours to 'decolonise theory' which I understand as an attempt to challenge colonial categories and epistemologies (Escobar 2007; Grosfoguel 2008; Mignolo 2000).

Furthermore, I argue that domestic workers have produced a phenomenon of 'transnationalisation from below' whereby their subaltern epistemology of rights has resonated with, and been adapted to, a mainstream international discourse on 'decent work.' Domestic workers' demands are not disconnected from international discourses or movements; however, they differ from a process of vernacularisation. More than a translation 
of pre-existing global frameworks into local demands, this is a case of subaltern discourses shaping the international field. I am not claiming that Brazilian domestic workers on their own have made ILO Convention 189 possible, but rather that their struggles invite us to rethink the South as a potential place of rights production.

\section{A subaltern epistemology of rights: framing domestic work as work}

The Brazilian state and economy have emanated from its colonial history, and are marked by gendered and racial divisions of labour. Black women have traversed from enslaved servants to poorly paid domestic workers, enabling white women to access more qualified and highly aid professions (Bruschini 2007; Lovell 2006). Domestic work today is still characterised by high levels of informality, lower wages, lower levels of protection, and abusive and stratified relationships with employers (Ávila 2016; Brites 2014; De Souza and Cerqueira 2009; DIEESE 2013). Crucially, this direct legacy of slavery has meant that domestic work was not recognised as proper work but as 'help' provided to households, and the 'natural' place of black women. Creuza Maria de Oliveira (interview by the author, 7 August 2015), leader of the FENATRAD, describes this historical continuity as follows:

The struggle of domestic workers in Brazil has to do with gender, race and class. There is still a remnant, or a historical process, from the movement against slavery. We, black women and black men, were trafficked from Africa and brought here to Brazil. The majority worked in the plantations, the others worked at the master's house.

As a result, domestic workers were legally excluded from the labour rights framework established in the 1930s. This period corresponds to the consolidation of the modern corporatist state, which connects citizenship to the status of workers. In 1931, the government adopted Law no 19.770/1931 which gave workers the right to unionise, but excluded domestic workers (article 11). Other labour rights such as the right to paid annual leave (Law no 23.103/1933) and the right to a minimum wage (Constitution of 1934, article 21) were adopted in the 1930s, with urban and industrial workers in mind. Labour rights were then consolidated in the 1943 Labour Code (Consolidação das Leis do Trabalho, or CLT), which excludes domestic workers from legal protection. The code defines domestic service as a 'non-economic service provided to families in their private homes' (CLT 1943, Title 1, article 7), thereby justifying their exclusion from labour regulations. If domestic workers are not workers, they do not qualify for labour rights.

It is in this context that Laudelina de Campos Mello (1904-1991) created the first association of domestic workers in 1936, demanding their inclusion in social security systems and the right to unionise (Pinto 2015). The association was structured on the model of religious charities, providing a place for empregadas who were getting too old or too sick to rest in dignity (STDMSP 2001). This year is commonly regarded as the formal start of the domestic workers' political movement, but there is evidence that they demanded better treatment as early as the $19^{\text {th }}$ century (see for instance Silva 2016). A study by Lima 
(2015) shows that in the pre-abolition period, some free women litigated against their male employers, demanding remuneration for their services as domestic workers. Based on these legal cases, Lima argues that we can see the emergence of a notion of labour rights connected to the idea of citizenship, and a framing of domestic service as work that deserves remuneration. Thus, ideas of work and rights were constructed in opposition to slavery, and this has shaped domestic workers' demand for recognition as proper workers, a status distinct from that of the slave.

In the 1960s, the Youth Catholic Workers (Juventude Operária Católica, or JOC), a branch close to the Theology of Liberation, helped to create associations of domestic workers in the cities of São Paulo, Rio de Janeiro, Recife, Salvador (all in 1962), while dona Laudelina, with the support of the black movement and the Communist Party, founded the association of Campinas in 1961 (FENATRAD 2002). In 1968, domestic workers organised their first national conference, and drafted a Bill demanding inclusion under existing labour laws (STDMSP 2001). At their 1976 national conference, domestic workers demanded a 10-hour work day with a one-hour lunch break, the minimum wage, compensation for night shifts, and full inclusion in the CLT (Kofes 2001: 308). In the 1980s, domestic workers' associations joined the struggles for the democratisation of the country. Many of them took part in the foundation of the Workers' Party (Partido dos Trabalhadores, or PT) and its affiliated trade union congress, the Unified Central of Workers (Central Única dos Trabalhadores, or CUT).

In 1985, at their fifth national conference, domestic workers demanded the rights contained in the 2015 legislation, namely to qualify for the national minimum wage, a notice period, compensation for unfair dismissal, access to unemployment benefits, a limit on working time and compensation for extra time (Bernardino-Costa 2015; Carvalho 1999). Domestic workers then got involved in the Constitution-writing process; among other things, they sent three buses carrying 500 domestic workers to Brasília to exert pressure on the transitional government, and proposed an amendment containing their demands which won the support of feminist groups (Sindomésticos Recife 1989). However, article 7 of the version of the Constitution adopted in 1988 reproduces their exclusion from the Labour Code, and limits their rights to eight items: freedom to form labour unions, a minimum wage, a $13^{\text {th }}$ salary, one day off a week, annual paid leave, maternity leave, a notice period and pensions (Constituição Federal 1988, Article 7).

The 1988 Constitution, often referred to as the 'Citizen's Constitution,' remains only a partial victory for domestic workers. On the one hand, it gives them the right to unionise, which is vital because, as argued by Lenira Carvalho, one of the oldest leaders of the union of Recife, 'the union is the body that tells society that we are a category of workers' (Carvalho 1999: 94). Domestic workers also secured some fundamental rights that they had demanded for decades, such as the right to a minimum wage (although this has not been enforced), and basic social benefits. On the other hand, the Constitution retained their exclusion from the CLT, maintaining the distinction between workers and non-workers, productive and non-productive labour, and - consequently - citizens and less-than-citizens. 
From 1988 onwards, most local associations of domestic workers transformed themselves into trade unions, thereby gaining ownership of the right to represent their profession, and mediate in labour disputes with employers. In 1997 they formed the FENATRAD and affiliated to the CUT. Throughout the 1990s, domestic workers' unions kept on pressing for equal rights, and particularly for two measures: access to unemployment benefits and limited working hours (CNTD 1996). Union leaders I interviewed for this study perceived the absence of limited working time as a characteristic of slave labour; it makes domestic workers totally disposable.

Throughout their decades of mobilisation, domestic workers have developed a powerful analysis of the value of their labour. They categorically refuse to accept the idea that domestic work is non-productive and position it as fundamental to every other form of work. A pamphlet produced in 1989 states:

The tasks that we perform are indispensable to the rest of society. They guarantee hygiene to and feeding of thousands of workers; the future workers - CHILDREN. They allow men and women, who work outside their homes, to regain their strength daily. Without our daily contribution, the other workers would have to earn more, or work less. Indeed, only this way would they be able to take care of their families and of themselves. Our work within the home complements the public work of the rest of the society! (Sindomésticos Recife 1989: 7).

Crucially, domestic workers argue that they produce wellbeing and reproduce the labour power of other workers. Lúcia Helena Conceição de Souza (interview by the author, 2 August 2017), president of the union of Volta Redonda, affirms:

Domestic work is the worst and the best of all jobs. It creates education, health and wellbeing. If domestic work ends, all the other professions will end too. Everyone needs a domestic worker; the doctor, the professor, they all need someone to take care of their house, their children, and cook them food. If domestic work ends, Brazil ends. It is a very important job, but people don't value it at all.

Fundamentally, domestic workers reclaim domestic and care work as being productive and valuable, against centuries of its devaluation. They contest the coloniality of labour (Gutierrez-Rodriguez 2014; Quijano 2000) and the racial and gendered hierarchies produced by it. They propose a radically counter-hegemonic vision of society in which the labour of black women is as valuable as that of anyone else, and where they are considered as workers in their own right. They demand equality, and by doing so, challenge the reigning social hierarchy. 
Figure 1 - FENATRAD poster n.1:

'Domestic work is a profession'

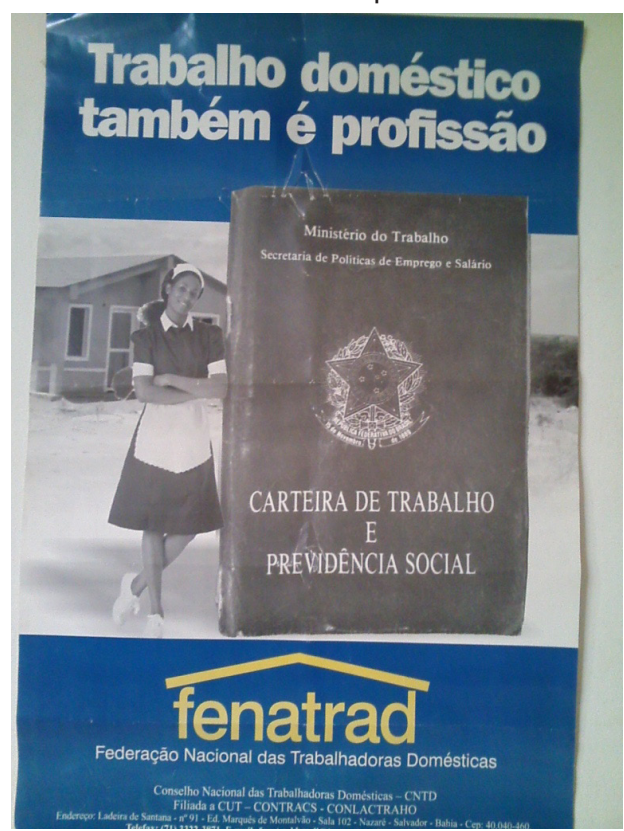

Source: Picture taken by the author.

Figure 2 - FENATRAD poster n.2:

'Domestic work is a profession'

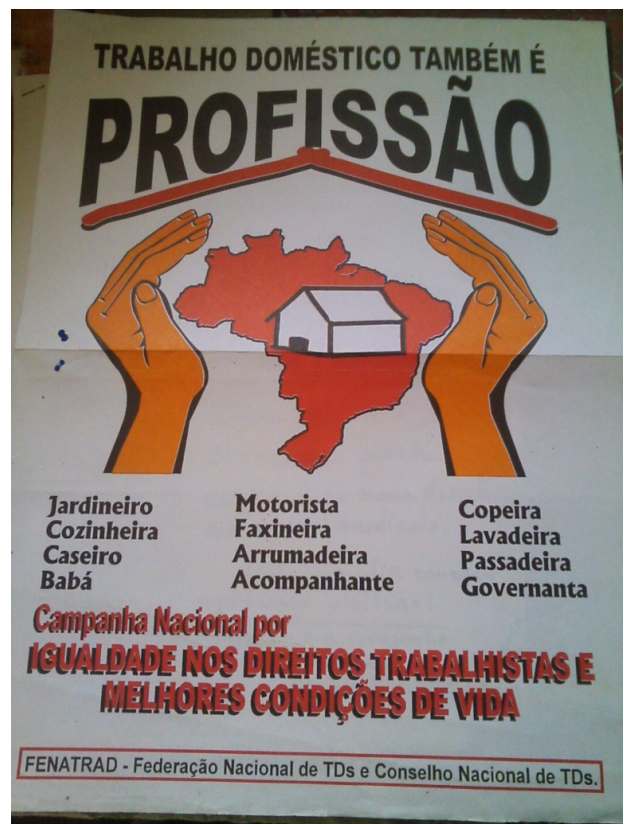

Source: Picture taken by the author. 
The rise to power of the PT in 2002 opened a new political opportunity for the domestic workers' movement. Positioning itself as the party of the poor, the PT was more inclined to listen to, or at least consult with, social movements and labour unions. Having a national federation affiliated to CUT has proven crucial for domestic workers; it made them the natural allies of the PT. Since 2003, the FENATRAD has formed part of the National Council for Women's Rights, a consultative body attached to the Secretariat of Policies for Women (Secretaria Especial de Politicas Para as Mulheres, or SPM), and of the National Council for the Promotion of Racial Equality, attached to the Secretariat for the Promotion of Racial Equality (Secretaria de Políticas de Promoção da Igualdade Racial, or SEPPIR). ${ }^{3}$ Through their participation in these structures, domestic workers were embedded within multiple programmes on child labour, modern slavery, human rights, the formalisation of work, gender equality and anti-racism. Located at the intersection of gender, race and class oppression, domestic workers appeared to be one of the most marginalised groups in Brazil, thus requiring urgent remedial action from the state. They became unavoidable for a government concerned with reducing social inequalities.

The SPM was in charge of drafting the Constitutional Amendment of 2013, also known as 'PEC das domésticas,' which states that: 'this alters the redaction of the unique paragraph of article no. 7 of the Federal Constitution in order to establish equality of rights between domestic workers and other urban and rural workers' (EC 72/2013, article 1). The amendment was then translated into law $150 / 2015$, which specifies the labour rights domestic workers are entitled to. These include the obligation of employers to sign a work card, the national minimum wage, a $13^{\text {th }}$ salary, remuneration of night work, an eight-hour working day and 44-hour working week, compensation for extra time, weekly rest, 30 days of paid annual leave, compensation for unfair dismissal, unemployment benefits, parental leave, sick pay, pension and the recognition of collective agreements (Law no 150/2015).

By affirming that domestic workers are workers, the 2013 Constitutional Amendment and its associated law of 2015 represent a significant change in Brazilian society, and has even been described as a 'second abolition of slavery' by elected politicians. This legislative victory seems to confirm Blofield's analysis that domestic workers can win rights with a combination of political mobilisation, the support of allies (feminist, black, religious and class-based movements) and the election of a left-wing government (Blofield 2012). However, the Constitutional Amendment did not end the exclusion of domestic workers from the CLT, thereby perpetuating their status as less-than-equal. This can be understood as an expression of the coloniality of labour; allowing domestic workers to fall under the Labour Code would radically redefine the nature of work and who qualifies as a worker, thus expanding notions of citizenship and rights. In this sense, the demands of domestic workers for equal labour rights constitute a subaltern epistemology of right and offer a decolonial conception of labour. 


\section{Transnationalising the labour rights discourse from below}

In 1988, together with domestic workers from Argentina, Bolivia, Colombia, Chile, Costa Rica and Guatemala, Brazilian domestic workers helped to establish the Confederation of Domestic Workers of Latin America and the Caribbean, or CONLACTRAHO (Sindomésticos Recife 1989). CONLACTRAHO became a key vehicle for making domestic workers' voices heard at the international level, and promoting a vision of domestic work as work. Despite a variety of organisational models and tactics, domestic workers' demands were fairly consistent across the continent from the start, including the recognition of their status as workers, legal right to a minimum wage, access to social security and the right to unionise. Indeed, before the 1990s, most countries did not limit working hours, and excluded domestic workers from the right to a minimum wage and social security (Blofield 2012). CONLACTRAHO also promoted a vision of domestic work as valuable work (CONLACTRAHO 1997).

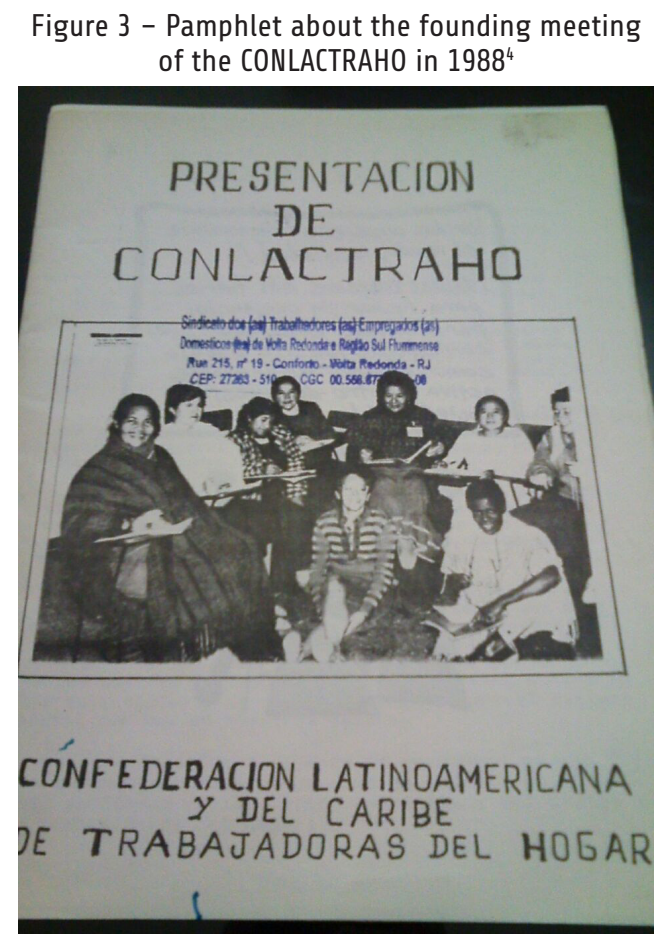

Source: Picture taken by the author.

This transnational network enabled domestic workers to attract funding from international organisations such as the ILO and UN Women. A pamphlet from 2002 mentions the organisation of a workshop by the ILO in Costa Rica and the launching of a study on the conditions of domestic workers in Latin America funded by the Ford Foundation (CONLACTRAHO 2002). In Brazil, the ILO supported the programme 'Domestic Work and Citizenship' (Trabalho Doméstico Cidadão, or TDC) introduced in 2006 by the PT 
government, which aimed to improve the level of literacy of domestic workers and to strengthen their unions (ILO 2011). The courses were designed with the input of the FENATRAD, and promoted a positive vision of domestic work as work, insisting on its value for society as a whole, thus echoing the discourses and demands of the domestic workers' unions:

Domestic work has an immense social importance, since it has an irreplaceable role in the reproduction of the workforce and for the well-being of people. Although an extensive part of this social reproduction is done in the domestic sphere, only a small share of this work is paid. [...] The valorisation of domestic work is an urgent demand to build a society that is fairer, more egalitarian and less discriminatory (ILO 2011).

This extract is reminiscent of the 1989 pamphlet cited earlier, and accurately reflects the narrative of union leaders interviewed in the course of this study. In 2005, the ILO also organised a seminar in conjunction with the CONLACTRAHO to discuss domestic workers' participation in trade union centres. At this occasion, participants signed a joint declaration stating that they would promote the adoption of a specific ILO Convention for domestic workers. The 2006 CONLACTRAHO Congress agreed to an action plan that reiterated the commitment to press for an ILO convention that would guarantee the labour rights of domestic workers (Valenzuela and Rangel 2008). By then, Uruguay (in 2006) and Bolivia (in 2003) had already approved legislation guaranteeing equal rights for domestic workers. In the same year, a global meeting was organised in Amsterdam at the initiative of the International Union Federation (IUF) and the NGO Women in Informal Employment (WIEGO), with the participation of international labour unions and representatives of domestic workers from around the world (Pape 2016). The discussions at this meeting also pointed towards the need for an ILO convention on domestic work.

This led to the creation of the International Domestic Workers Network (IDWN), which then became the International Domestic Workers Federation (IDWF), amalgamating organisations of domestic workers around the world. The IDWN's initial goal was to coordinate domestic workers globally so that they would present a united front at the ILO negotiations. In 2008, the ILO finally put domestic work on the agenda of the 2010 International Labour Conference (Fish 2017; Pape 2016). It is interesting to note that the first time the ILO mentioned the necessity to regulate domestic work was in 1936 as part of a growing concern about the employment of women (D'Souza 2010). In 1948, the $30^{\text {th }}$ International Labour Conference (ILC) declared that: 'the time has now arrived for a full discussion on this important subject' (ILC Resolutions 1948: 554, cited in D'Souza 2010). However, the issue of domestic work was adjourned and then dropped from the agenda until the 2000s.

In preparation of the 2010 ILC, member states received a questionnaire about the conditions and demands of domestic workers in their country. Research carried out by the ILO and evidence provided by member states, all suggested that domestic workers 
were among the least protected workers, which conflicted with the promotion of 'decent work' worldwide (D’Souza 2010; ILO 2008; ILO 2017). The combination of advocacy and research on migrant workers, 'modern slavery' and human trafficking further helped to make domestic workers' lack of rights more visible, and frame them as vulnerable subjects. Fish (2017) suggests that domestic workers astutely crafted their vulnerability to become a priority for policy-makers and for the ILO.

In Brazil, this period coincided with the PT government, which was - at least rhetorically - concerned with attending to the needs of the most vulnerable people. The FENATRAD was mobilised to respond to the ILO questionnaire and used this opportunity to reiterate its demands for equal labour rights. Leaders who had been involved in the TDC programme were called to form part of the consultative process and put in direct contact with the ILO. In August 2009, a workshop of 40 leaders of domestic workers' unions affiliated to the FENATRAD, representatives of UN Women and the ILO, and delegates from the SPM and SEPPIR, was held in Brasília to coordinate domestic workers' demands before the ILC (Sanches 2009). Brazil played a key role in the international negotiations, both through its government and through the FENATRAD which was allowed to participate in the negotiations as a member of CUT. Some accounts of the negotiations emphasise the leadership of the Brazilian delegation, particular that of Creuza Maria de Oliveira, who positioned herself as a legitimate representative of the entire region (Goldsmith 2013). Marcelina Bautista (interview by the author, 21 September 2016), general secretary of the CONLACTRAHO at the time of the ILO negotiations, confirmed:

Comrades from other countries would look up to the Brazilian delegation before the votes. They appeared so much more prepared and so strong, that other Latin American countries would follow their lead for major decisions. We were all impressed by the strength of the movement in Brazil and the charisma of our comrades.

Regina Teodoro, from the union of Campinas, was one of the Brazilian delegates at the 2010 and 2011 ILCs where the negotiations took place. She explains that even though language was a barrier - Brazilian delegates did not speak Spanish or English - they managed to set up a regional group and coordinate their demands before going to the plenary sessions:

This process is very interesting. The rules they have, I mean, the rules are this thing that is very strict. On many occasions, I was interrupted by the little gavel (laughs), we had to be quiet, we couldn't applaud, we had to wait our turn to speak, we couldn't stay in the room after the debates ... but because everything went in the opposite direction of what we wanted, we had to protest. And we didn't speak Spanish, so we had to tell another person to say this or that, then the person had to speak and translate back to us. Then we started making noise to actually interrupt, because we were running out of time because of the translation. We finally got the trick. And on 
the fifth day, countries that did not have domestic workers' unions started following us during the votes (Regina Teodoro, interview by the author, 5 May 2016).

According to Regina Teodoro, domestic workers were able to impose their rhythm and make their demands heard. For once, domestic workers were not invisible; they were in the forefront of an international tripartite negotiation. Domestic workers' physical presence inside the ILO made it harder, or even untenable, for representatives of employers and governments to deny them the basic rights they were asking for (Fish 2017; Pape 2016). The entrance of the subaltern into this international institutional arena made them an unavoidable issue, and made their lack of rights an immoral condition.

Approved by a large majority of delegates on 16 June 2011 at the $100^{\text {th }}$ International Labour Conference, ILO Convention 189 has been described as historic (Goldsmith 2013; Oelz 2014), and Blackett (2012) argues that it represents a fundamental shift to a 'human right to labour rights.' Its recommendations include freedom of association and the right to collective bargaining; the elimination of all forms of forced or compulsory labour; the effective abolition of child labour; and the elimination of discrimination in respect of employment and occupation. To date, it has been ratified by 25 countries, including Brazil (in January 2018).

While the proactive role of the ILO should not be discounted, it is important to remember that the movement for equal labour rights for domestic workers started 80 years ago in Brazil, and about as long ago in some Latin American countries such as Argentina, Chile and Bolivia (Chaney and Castro 1989; Valenzuela and Rangel 2008). It was then formalised as a transnational movement in the 1980s, making the CONLACTRAHO the oldest and more structured regional network of domestic workers in the world (Pape 2016). This study cannot fully account for domestic workers' movements in other countries and continents, but strong movements have been existing in the global South for decades, among others in South Africa, Indonesia, India and Hong Kong (see for instance: Ally 2009; Bonner 2010; Jordhus-Lier 2017). In Brazil, the demands of domestic workers for labour rights and their full recognition as workers emerged in the 1930s, responding to specific political and legal circumstances. Those demands also resonated with domestic workers' movements in other locations, and, as argued by Dunford and Madhok (2015), transnational principles coexist and are embedded within local contexts and histories. In this sense, the exchange of knowledge and experience facilitated by CONLACTRAHO is quite important.

However, I argue that the case of domestic workers' rights is more than an act of vernacularisation or adaptation of a transnational rights framework (Kay 2011; Levitt and Merry 2009; Reilly 2011); instead, it is a case of what I call 'transnationalisation from below.' Indeed, the term 'vernacularisation' refers to a process in which local movements adapt 'globally generated ideas' (Levitt and Merry 2009) to their particular context, whereas I contend that the case of domestic workers' rights shows a reverse dynamic: the globalisation - and adaptation into an international Convention - of locally generated discourses on labour rights and equality. By this, I do not mean that Brazilian domestic 
workers on their own won ILO Convention 189, but rather that their history illustrates the possibility for subaltern movements to produce rights discourses and to transnationalise them. These discourses were also being formulated by domestic workers in other countries, which seems to indicate that the global movement has emanated from an aggregation of local demands rather than its creating the preconditions for local demands to exist.

Although Convention 189 provides domestic workers' movements with new leverage (Poblete 2018), the specific rights contained in it, like the rights guaranteed by the Brazilian 2015 legislation, were claimed and articulated decades before this institutional recognition. Therefore, this process reflects more domestic workers' ability to transnationalise their demands than a process of translating pre-existing global discourses into local demands. In this case, the very act of claiming a right went beyond demanding inclusion within an already existing framework; in Brazil, it transformed the rights framework itself and produced a new language of labour rights (Dunford and Madhok 2015; Madhok 2017).

\section{Challenging the colonial social order}

The Brazilian constitutional reform of 2013 means recognition at the highest level of the state that domestic work is work. By giving domestic workers access to basic labour rights, and inscribing those rights within the Constitution, the law expands social understandings of what counts as productive work. In this regard, the 2015 law brings a significant social change. Although incomplete because domestic workers remain excluded from the Labour Code, the law does, nonetheless, recognise private homes as workplaces subject to state regulations, challenging the public/private divide. The domestic sphere is acknowledged to be a place where labour is being sold and exchanged, and where care and wellbeing are being produced and reproduced (Federici 2012; Fraser 2016; Pearson 2004). It also recognises, although indirectly, reproductive work as work, with its associated rights and rules. This shift in conceptions of work, and who is worth being called a worker, deeply challenges the colonial structure of Brazilian society.

Consequently, the constitutional reform unleashed strong resistance from the elite. Employers' associations claimed that the new law would impose too high a burden on the middle-class, arguing that households are not private companies, that the value of domestic work is not the same as other work, and that the cost of giving equal rights to domestic workers would be unbearable for households. Parts of the elite saw the law on domestic work as a frontal attack on their centennial privileges. They revived a well-established narrative in which the employing household is really the exploited party. ${ }^{5}$ In 2013 , as the Constitutional Amendment was being approved, mainstream media published numerous reports about middle- and upper-class families who would be negatively affected by the reform. Many worried that it would cost too much to hire a maid. Some also insisted on the fact that most households would be forced to trade their cleaner for electronic devices such as dishwashers (Rito 2013). The magazine Veja, one of the most read in the country, 
even published testimonies of upper-class women complaining that it is not possible to check working hours at home. An employer said:

I don't know how to count costs related to the working day of my nanny, who sleeps at home. What is additional time? What's a night shift? Unlike companies, at home there isn't a clock to check on the worker (Honorato 2013).

This quotation reveals the core of the issue around domestic work: employers do not see themselves as employers, as they do not see domestic work as work. What happens in the privacy of the home cannot be compared to 'proper' work in a company. In another article published in 2015, upper class families explain that they are 'importing' nannies from the Philippines because they are more 'submissive' than Brazilian ones (Campos Mello 2015). A woman employer describing her Filipino nanny explains: 'she was incredible, she did the groceries, cleaned, cooked and drove. She even washed the car! In Brazil, a nanny is only a nanny, a cook only cooks, and a cleaner only cleans.' Here, the employer is praising the total disposability of labour of foreign nannies, reinforcing colonial and gendered hierarchies. A good employee is someone who is ready to do more for the same the wage, who has no fair terms and conditions, job description or labour demands. A good worker is a flexible, low-paid, disposable worker - a servant rather than a worker (Acker 2004; Cox 1997; Cox 2006; Parreñas 2001).

The figure of the domestic worker even became a subject of contestation during the 2016 political crisis and impeachment process, as if the newly gained rights of domestic workers exemplified everything that had gone wrong under the PT government. The middle and upper classes could no longer afford their privileges; their way of life was threatened. The polemic has intensified around the widely circulated image of a white upper-class couple demonstrating in favour of Dilma's impeachment in Copacabana in March 2016, followed by their black nanny, wearing her uniform, and pushing a pram (see image below) - a vivid illustration of the gendered and racial division of labour.

By refusing to see themselves as employers, middle- and upper-class households perpetuate the idea that domestic services should be provided at no cost, and outside the formal labour market. Their position confirms an entrenched coloniality of labour and legacy of slavery; indeed, the elite aspires to have servants with no working rights at their disposal. Black women are still expected to work for free for the white elite, enabling the latter to be 'productive,' play active political roles or have leisure time. Domestic work is presented as worthless as it is not proper work, and the aspiration of domestic workers to equal rights is framed as both economically unachievable and morally wrong, comprising a danger that could destroy society. Domestic workers' rights crystallise a centuries-old struggle between dominant colonial interests and subaltern aspirations to equality. In this regard, the 2015 law, and the ILO Convention 189, are a first step towards decolonising labour. 
Figure 4 - White couple demonstrating in Copacabana in favour of Dilma Rousseff's impeachment, followed by their black nanny

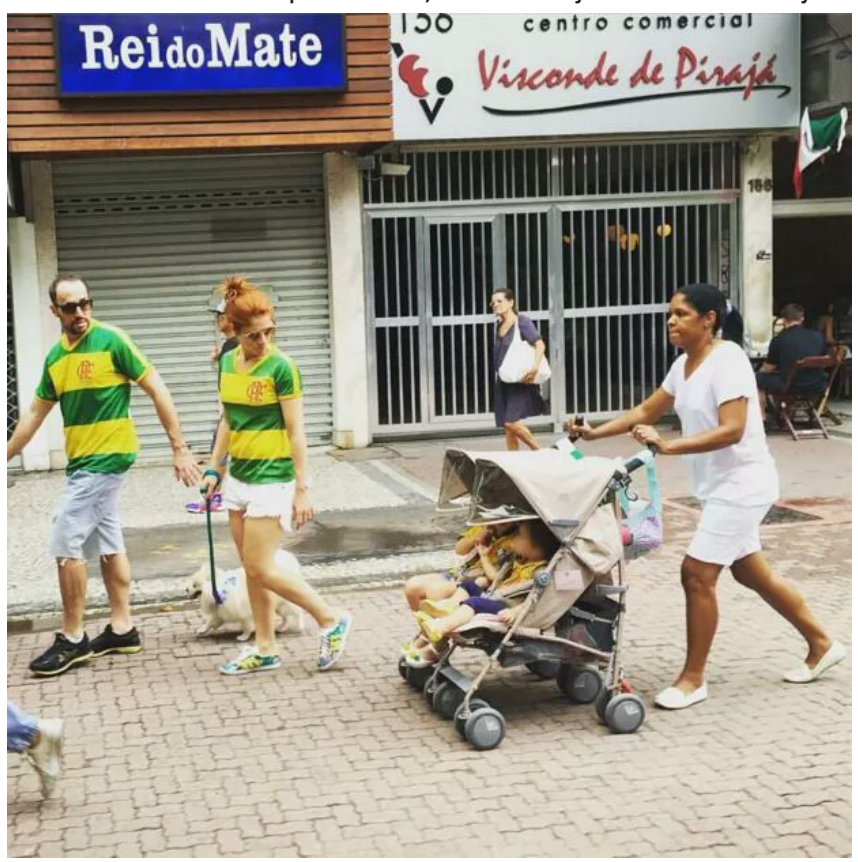

Source: Brasil 247 (2016).

\section{Conclusion}

This study tracks the genealogy of the labour rights discourse as imagined, articulated and mobilised by organised domestic workers in Brazil. It shows that domestic workers were already demanding full recognition as workers in the 1930s, and therefore as full citizens. Ideas of rights and citizenship were constructed in opposition to the status of slave and embedded within the Brazilian legal and political structures. However, it was only after 80 years of mobilisation that, in 2015, the Brazilian government approved a law extending most - but not all - labour rights to domestic workers. The PT government has presented this legislation as a 'second abolition of slavery' and a necessary step towards ratifying ILO Convention 189.

Yet the 2015 legislation must be understood as more than a 'boomerang effect' (Keck and Sikkink 1998), or a case of the 'vernacularisation' (Levitt and Merry 2009) of global rights. This specific labour rights discourse, as articulated by the domestic workers' movement, preceded both the ILO Convention and the Brazilian legislation, which demonstrates domestic workers' ability to be heard internationally and to influence the making of rights. I have called this process 'transnationalisation from below', to insist on the fact that subaltern movements can produce their own epistemology of rights and make it resonate at the transnational level. Indeed, I argue that the case of domestic workers' rights is not a 
simple adaptation of a pre-existing global framework at the local level, but an example of a subaltern movement producing a rights discourse and transnationalising it. This study does not pretend to explain the adoption of the ILO Convention, but rather serves to illustrate the longer history of the labour rights gained in Brazil in 2015, and to analyse the ways in which these rights have been framed and claimed by domestic workers. It shows that the global South should be conceived as a place of rights and knowledge production, and not only as a place of rights reception.

However, the 2015 Brazilian legislation remains limited. One of its most contentious measures is the different status given to daily workers (diaristas), defined as those who work for less than three days a week for the same employer (article 1). The diaristas are considered to be self-employed, and are therefore not covered by the new labour rights. More problematically, the legislation maintains domestic workers' exclusion from the CLT, thus perpetuating the idea that they are not really workers. In addition, after PT president Dilma Rousseff's impeachment in 2016, the new government adopted a new labour reform (reforma trabalhista) that deregulates the labour market and weakens the CLT (DIEESE 2017). Although this does not directly affect domestic workers, the new political context has introduced some new uncertainties about the implementation of domestic workers' rights, as well as their capacity to negotiate with the state.

Therefore, domestic workers' unions in Brazil face significant new challenges. They are trying to reclaim their agency in the legislative process while also demonstrating the limitations of the law, and need to remobilise their members to make their new - albeit partial - rights effective. Future research could track the effects of the 2015 legislation and ILO Convention 189 on the ground. For instance, what steps are being taken by the Brazilian state to implement Convention 189 and law 150/2015? And what difference does it make in the daily lives of domestic workers? A comparison with other Latin American countries could also show to what extent these legislative processes reflect domestic workers' demands. In Brazil, it will take more than the current law to justify the denomination of a 'second abolition of slavery'; as long as domestic workers are not included in the labour code, they will not be treated as proper workers.

\section{Notes}

1 Formal work is characterised in Brazil by having a work card (Carteira de Trabalho e Providência Social CTPS) signed by the employer. This card is compulsory for every worker, and is provided by the Ministry of Labour.

2 Known as the Domestic Workers Convention, 2011 (No. 189), its full title is 'Convention concerning decent work for domestic workers.' It entered into force on 5 September 2013.

3 These two structures were dismantled by the post-impeachment government in 2016, and reorganised under the Ministry of Justice.

4 The person on the far left is Nair Jane de Castro Lima, a former leader of the union of the city of Rio de Janeiro, and currently leader of the union of the city of Nova Iguaçu. She represented Brazil at the founding meeting of the CONLACTRAHO.

5 In 1961, an employer sent a letter to Laudelina de Campos Mello which read: 'Despite this comfort that empregadas benefit from, $90 \%$ are vain, disobedient, disrespectful, humiliating the poor martyr patroa with irreverent words!' (Bernardino-Costa 2015: 85). 


\section{References}

Abu-Lughod, L. 2002. 'Do Muslim women really need saving? Anthropological reflections on cultural relativism and its others.' American Anthropologist 104 (3): 783-790.

Acker, J. 2004. 'Gender, capitalism and globalization.' Critical Sociology 30 (1): 17-41.

Ally, S. 2009. From Servants to Workers: South African Domestic Workers and the Democratic State. New York: Cornell University Press.

Ávila, M B. 2016. 'O tempo do trabalho doméstico remunerado: entre cidadania e escravidão.' In A R de P Abreu, H Hirata and M R Lombardi, Gênero e trabalho no Brasil e na França: perspectivas internacionais. São Paulo: Boitempo, pp. 137-149

Barreto, J-M. 2012. 'Decolonial strategies and dialogue in the human rights field: a manifesto.' Transnational Legal Theory 3 (1): 1-29.

Bernardino-Costa, J. 2007. 'Sindicatos das trabalhadoras domésticas no Brasil: teorias da descolonização e saberes subalternos.' Sociedade e Estado 22 (1): 197-206.

. 2015. Saberes subalternos e decolonialidade: os sindicatos das trabalhadoras domésticas no Brasil. Brasilia: Editora UnB.

Blackett, A. 2012. 'The decent work for domestic workers convention and recommendation, 2011.' The American Journal of International Law 106 (4): 778-794.

Blofield, M. 2012. Care Work and Class: Domestic Workers' Struggle for Equal Rights in Latin America. University Park: Pennsylvania State University Press.

Bo Nielsen, K. 2015. 'Law and Larai: the (de)judicialisation of subaltern resistance in west Bengal.' Journal of Contemporary Asia 45 (4): 618-639.

Bonner, C. 2010. 'Domestic workers around the world: organising for empowerment.' In Social Law Project Conference. Cape Town: WIEGO.

Bradshaw, S. 2006. 'Is the rights focus the right focus?: Nicaraguan responses to the rights agenda.' Third World Quarterly 27 (7): 1329-1341.

Brasil 247 [online]. 2016. 'Ícone da nova luta de classes, banqueiro diz gostar da babá.' 14 March. At https://www.brasil247.com/pt/247/rio247/220943/Ícone-da-nova-luta-de-classes-banqueiro-dizgostar-da-babá.htm [Accessed on 18 July 2018].

Brinks, D M, V Gauri and K Shen. 2015. 'Social rights constitutionalism: negotiating the tension between the universal and the particular.' Annual Review of Law and Social Science 11 (1): 289-308.

Brites, J. 2014. 'Domestic service, affection and inequality: elements of subalternity'. Women's Studies International Forum 46: 63-71.

Brown, W. 2000. 'Suffering rights as paradoxes.' Constellations 7 (2): 208-229.

Bruschini, M C A. 2007. 'Work and gender in Brazil in the last ten years.' Cadernos de Pesquisa 37 (132): 537-572.

Campos Mello, P. 2015. 'Empresa 'importa’ babás e domésticas das Filipinas para o Brasil.' Folha de São Paulo, 10 May.

Carvalho, L. 1999. A luta que me fez crescer. Recife: Deutscher Entwicklungsdienst.

Chaney, E and M G Castro. 1989. Muchachas No More: Household Workers in Latin America and the Caribbean. Philadelphia: Temple University Press. 
Chua, L J. 2015. 'The vernacular mobilization of human rights in Myanmar's sexual orientation and gender identity movement.' Law \& Society Review 49 (2): 299-332.

Conselho Nacional das Trabalhadoras Domésticas (CNTD). 1996. Minutes of the National Council of Domestic Workers meeting of 9 and 10 November 1996. Internal Notes.

Collins, D, S Falcón, S Lodhia and M Talcott. 2010. 'New directions in feminism and human rights.' International Feminist Journal of Politics 12 (3-4): 298-318.

Confederation of Domestic Workers of Latin America and the Caribbean (CONLACTRAHO). 1997. Por un nuevo despetar (pamphlet).

2002. Por un nuevo despetar (pamphlet).

Cornwall, A, S Corrêa and S Jolly. 2008. Development with a Body: Sexuality, Human Rights and Development. London: Zed Books.

Cornwall, A and M Molyneux. 2006. 'The politics of rights: dilemmas for feminist praxis: an introduction.' Third World Quarterly 27 (7): 1175-1191.

Corrêa, S. 2016. 'A categoria mulher não serve mais para a luta feminista.' Sur - Revista Internacional de Direitos Humanos 13 (24): 215-225.

Costa Furno, J. 2016. 'A longa abolição no Brasil: transformações recentes no trabalho doméstico.' Masters dissertation, Universidade Estadual de Campinas (UNICAMP), Brazil.

Couso, J. 2007. 'The limits of law for emancipation (in the South).' Griffith Law Review 16 (2): 330-352.

Couso, J, A Huneeus and R Sieder. 2013. Cultures of Legality: Judicialization and Political Activism in Latin America. Cambridge: Cambridge University Press.

Cox, R. 1997. 'Invisible labour: perceptions of paid domestic work in London.' Journal of Occupational Science 4 (2): 62-67.

2006. The Servant Problem: Domestic Employment in a Global Economy London: I B auris.

Central Única dos Trabalhadores do Rio de Janeiro (CUT-RJ) and Sintell-Rio. 2013. 'Trabalho doméstico: a conquista de direitos e cidadania.' Rio de Janeiro.

D’Souza, A. 2010. 'Moving towards decent work for domestic workers: an overview of the ILO's work.' ILO Working Paper 2/2010: 1-94.

Della Porta, D and S G Tarrow. 2005. Transnational Protest and Global Activism. Lanham: Rowman \& Littlefield.

De Souza, E R and E Cerqueira. 2009. 'From the kitchen to the bedroom: frequency rates and consequences of sexual harassment among female domestic workers in Brazil.' Journal of Interpersonal Violence 24 (8): 1264-1284.

Departamento Intersindical de Estatística e Estudos Socioeconômicos (DIEESE). 2013. 'O Emprego Doméstico no Brasil.' Estudos e Pesquisas 1-27.

2017. 'A Reforma Trabalhista e os impactos para as relações de trabalho no Brasil'. Nota Técnica - Número 178: 1-22.

DIEESE and FES. 2015. 'Perfil das/os trabalhadoras/es domésticas/os no município de São Paulo.' Pesquisa de Emprego e Desemprego (PED): 1-53.

Dufour, P and I Giraud. 2007. 'The continuity of transnational solidarities in the world march of women, 2000 and 2005: a collective identity-building approach.' Mobilization 12 (3): 306-322. 
Dunford, R F and S Madhok. 2015. 'Vernacular rights cultures and the "right to have rights." Citizenship Studies 19 (6-7): 605-619.

Escobar, A. 2007. 'Worlds and knowledges otherwise: the Latin American modernity/ coloniality research program.' Cultural Studies 21 (2-3): 179-210.

Federici, S. 2012. Revolution at Point Zero: Housework, Reproduction, and Feminist Struggle. Oakland: PM.

Federação Nacional das Trabalhadoras Domésticas (FENATRAD). 2002. Relatório do encontro nacional. Internal notes.

Fish, J. 2017. Domestic Workers of the World Unite! A Global Movement for Dignity and Human Rights. New York: New York University Press.

Fraser, N. 2016. 'Contradictions of capital and care.' New Left Review 100: 99-117.

García-Del Moral, P. 2016. 'Feminicidio, transnational human rights advocacy and transnational legal activism: beyond vernacularization.' Conference Papers - American Sociological Association: $1-45$.

Gideon, J. 2006. 'Accessing economic and social rights under neoliberalism: gender and rights in Chile.' Third World Quarterly 27 (7): 1269-1283.

Golder, B. 2014. 'Beyond redemption? Problematising the critique of human rights in contemporary international legal thought'. London Review of International Law 2 (1): 77-114.

Goldsmith, M. 2013. 'Los espacios internacionales de la participación política de las trabajadoras remuneradas del hogar.' Revista de Estudios Sociales 45: 233-246.

Grosfoguel, R. 2008. 'Transmodernity, border thinking, and global coloniality'. Eurozine: 1-23.

Gutiérrez-Rodriguez, E. 2014. 'Domestic work-affective labor: on feminization and the coloniality of labor.' Women's Studies International Forum 46: 45-53

. 2013. 'The precarity of feminisation: on domestic work, heteronormativity and the coloniality of labour.' International Journal of Politics, Culture and Society 27: 191-202.

Honorato, R. 2013. 'PEC das domésticas pode elevar despesas de famílias com empregados em quase 40\%.' Veja, 24 March.

International Labour Organization (ILO). 2008. 'Decent work for domestic workers.' Labour Education 2007/3-4.

. 2011. Guia para programas de qualificação para as trabalhadoras domésticas. Brasilia: ILO.

2011. Convention 189. At http://www.ilo.org/dyn/normlex/en/f?p=NORMLEXPUB:12100:0 ::NO::P12100_INSTRUMENT_ID,P12100_LANG_CODE:2551460,en [Accessed on 18 July 2018].

2013. 'Domestic workers across the world: global and regional statistics and the extent of legal protection.' Geneva: ILO.

2016. 'Global estimates on migrant workers.' ILO, Labour Migration Branch. Geneva. 1-100.

2017. 'Implementation of international labour standards for domestic workers.' What Works

- Research Brief 9: 1-5.

Jacquot, S and T Vitale. 2014. 'Law as weapon of the weak? A comparative analysis of legal mobilization by Roma and women's groups at the European level.' Journal of European Public Policy 21 (4): 587-604. 
Jordhus-Lier, D. 2017. 'Claiming industrial citizenship: the struggle for domestic worker rights in Indonesia.' Norsk Geografisk Tidsskrift - Norwegian Journal of Geography 71 (4): 243-252.

Kabeer, N. 2004. 'Globalization, labour standards, and women's rights: dilemmas of collective (in) action in an interdependent world.' Feminist Economics 10 (1): 3-35.

2015. 'Tracking the gender politics of the Millennium Development Goals: struggles for interpretive power in the international development agenda.' Third World Quarterly 36 (2): 377-395.

Kay, T. 2011. 'Legal transnationalism: the relationship between transnational social movement building and international law. Law \& Social Inquiry 36 (2): 419-454.

Keck, M E and K Sikkink. 1998. Activists beyond Borders: Advocacy Networks in International Politics. London: Cornell University Press.

Kofes, M S. 2001. Mulher, mulheres: identidade, diferença e desigualdades na relação entre patroas e empregadas domésticas. Campinas: UNICAMP.

Levitt, P and S Merry. 2009. 'Vernacularization on the ground: local uses of global women's rights in Peru, China, India and the United States.' Global Networks 9 (4): 441-461.

Lima, H E. 2015. 'Wages of intimacy: domestic workers disputing wages in the higher courts of nineteenth-century Brazil.' International Labor and Working-Class History 88: 11-29.

Lovell, P A. 2006. 'Race, gender, and work in São Paulo, Brazil, 1960-2000.' Latin American Research Review 41 (3): 63-87.

Lugones, M. 2010. 'Towards a decolonial feminism.' Hypatia 25 (4): 742-759.

MacKinnon, C A. 1994. 'Rape, genocide, and women's human rights.' Harvard Women's Law Journal 17: 5-17.

Madhok, S. 2017. 'On vernacular rights cultures and the political imaginaries of Haq.' Humanity: An International Journal of Human Rights, Humanitarianism, and Development 8 (3): 485-509.

Mahmood, S. 2011. 'Religion, feminism, and empire: the new ambassadors of islamophobia.' In L Alcoff and J Caputo (eds), Feminism, Sexuality and the Return of Religion. Bloomington: Indiana University Press, pp. 77-103

Mignolo, W. 2000. Local Histories/Global Designs: Coloniality, Subaltern Knowledges, and Border Thinking. Princeton: Princeton University Press.

2011. 'Geopolitics of sensing and knowing: on (de)coloniality, border thinking and epistemic disobedience.' Postcolonial Studies 14 (3): 273-283.

Mohanty, C T. 1988. 'Under western eyes: feminist scholarship and colonial discourses.' Feminist Review 30: 61-88.

Molyneux, M and S Razavi. 2002. Gender Justice, Development, and Rights. Oxford: Oxford University Press.

Oelz, M. 2014. 'The ILO’s domestic workers convention and recommendation: a window of opportunity for social justice.' International Labour Review 153 (1): 143-172.

Pape, K. 2016. 'ILO Convention C189 - a good start for the protection of domestic workers: an insider's view.' Progress in Development Studies 16 (2): 189-202.

Parreñas, R S. 2001. Servants of Globalization: Women, Migration and Domestic Work. Palo Alto: Stanford University Press. 
Pearson, R. 2004. 'The social is political: towards the re-politicization of feminist analysis of the global economy' International Feminist Journal of Politics 6 (4): 603-622.

Pinho, P de S and E B Silva. 2010. 'Domestic relations in Brazil: legacies and horizons.' Latin American Research Review 45 (2): 90-113.

Pinto, E A. 2015. Etnicidade, gênero, e educação: trajetória de vida de Laudelina de Campos Mello. São Paulo: Anita Garibaldi.

Poblete, L. 2018. 'The influence of the ILO Domestic Workers Convention in Argentina, Chile and Paraguay.' International Journal of Comparative Labour Law and Industrial Relations 34 (2): 177-202. Quijano, A. 2000. 'Coloniality of power and eurocentrism in Latin America.' International Sociology 15 (2): $215-232$.

.2007. 'Questioning “race."' Socialism and Democracy 21 (1): 45-53.

Rajaram, N and V Zararia. 2009. 'Translating women's human rights in a globalizing world: the spiral process in reducing gender injustice in Baroda, India.' Global Networks 9 (4): 462-484.

Reilly, N. 2011. 'Doing transnational feminism, transforming human rights: the emancipatory possibilities revisited.' Irish Journal of Sociology 19 (2): 60-76.

Ritto, C. 2013. 'Sai a empregada, entra a lava-louça.' Veja, 13 April.

Sanches, S. 2009. 'Trabalho doméstico: desafios para o trabalho decente.' Revista Estudos Feministas 17 (3): 879-888.

Sieder, R, L Schjolden and A Angell. 2005. The Judicialization of Politics in Latin America. New York: Palgrave MacMillan.

Sikkink, K. 2005. 'Patterns of dynamic multilevel governance and the insider-outsider coalition.' In D Della Porta and S G Tarrow (eds), Transnational Protest and Global Activism. Lanham: Rowman \& Littlefield, pp. 151-175

2014. 'Latin American countries as norm protagonists of the idea of international human

rights.' Global Governance 20 (3): 389-404.

Silva, M H C. 2016. Nem mãe preta, nem negra fulô: histórias de trabalhadoras domésticas em Recife e Salvador (1870-1910). São Paulo: Paco Editorial.

Sindomésticos Recife. 1989. Domésticas: Uma Categoria da Classe Trabalhadora. Seus Direitos, Suas Lutas, Suas Propostas. Recife: Sindomésticos

Sousa-Santos, B and C A Rodríguez-Garavito. 2005. Law and Globalization from Below: Towards a Cosmopolitan Legality. Cambridge: Cambridge University Press.

Spivak, G C. 2003. 'Righting wrongs.' In Nicholas Owen (ed), Human Rights, Human Wrongs. Oxford: Oxford University Press, pp. 168-227.

Sindicato dos Trabalhadores Domésticos do Município de São Paulo (STDMSP). 2001. História de uma Luta. São Paulo.

Valenzuela, M E and M Rangel. 2008. 'Latin America's domestic workers - the ones decent work forgot.' ILO Decent Work for Domestic Workers, Labour Education, 2007/3-4: 63-69. 


\section{Interviews}

Oliveira, Creuza Maria de. 2015. President of the FENATRAD at the time of the interview. Salvador. 7 August.

Souza, Lúcia Helena Conceição de. 2017. President of the union of Volta Redonda at the time of the interview. Volta Redonda. 2 August.

Bautista, Marcelina, 2016. Secretary for Latin America at the IDWF at the time of the interview. Rio de Janeiro. 21 September.

Teodoro, Regina, 2016. Leader of the union of Campinas at the time of the interview. Campinas. 5 May.

\section{Acknowledgements}

I would like to thank all the domestic workers I have met during this study for opening the doors of their unions and their homes to me. In particular, I want to thank Eliete, Kota, Regina, Maria Lima, Silvia, Rosa, Dilma, Cristina, Cleide, Nair Jane, Lourdes, Lúcia Helena, Jorgina, Carli, Noeli, Luiza and Creuza.

\section{About the author}

Louisa Acciari holds a PhD from the London School of Economics and Political Science (LSE), and an MSc from Sciences Po Paris. She is currently researching the unionisation of domestic workers in Brazil and their demands to be recognised as workers. Louisa has been involved in collaborative work with domestic workers' unions since 2015, and is currently working with the ILO-Brazil to develop and implement training material to strengthen domestic workers' organisational capacity. Her research interests include subaltern studies, social movements, industrial relations, feminist theory and Brazilian politics. 


\title{
Descolonizando o Trabalho, Recuperando Epistemologias Subalternas: As Trabalhadoras Domésticas Brasileiras e a Luta Internacional por Direitos Trabalhistas
}

\begin{abstract}
Resumo: Este artigo explora o discurso sobre direitos trabalhistas produzido por trabalhadoras domésticas no Brasil. Isso mostra que a legislação brasileira de 2015 que estende os direitos trabalhistas à categoria das trabalhadoras domésticas não é simplesmente um 'efeito boomerangue' da Convenção 189 de OIT sobre trabalho decente para trabalhadoras domésticas, ou um caso de 'vernacularização' de direitos globais dentro de demandas locais. De fato, as trabalhadoras domésticas têm se mobilizado para direitos trabalhistas igualitários desde 1936, e já haviam articulado os direitos específicos contidos na nova legislação décadas antes de seu reconhecimento institucional. Portanto, mais do que um caso de tradução dos quadros globais já existentes em nível local, o caso das trabalhadoras domésticas demonstra a capacidade que grupos subalternos tem para transnacionalizar suas demandas, sugerindo que o Sul global não deve ser concebido apenas como um local de recebimento de direitos, mas também como um local de produção de direitos. Assim, eu proponho traçar a genealogia do discurso de direitos trabalhistas como imaginado e mobilizado pelas trabalhadoras domésticas no Brasil, e examinar as maneiras com as quais esse discurso viajou entre sua localização subalterna, o Estado Brasileiro e a agenda internacional do 'trabalho decente'.
\end{abstract}

Palavras-chave: trabalho doméstico; direitos trabalhistas; saber subalterno; Brasil; movimentos transnacionais.

Received on 30 January 2018, and approved for publication on 2 October 2018.

\section{(c)) BY-NC} https://creativecommons.org/licenses/by-nc/4.0/ 